\title{
Routine blood report and common laboratory parameters in COVID-19: Experience from Bangladesh
}

\author{
Md. Khairul Islam ${ }^{1}$, Mohammad Murad Hossain ${ }^{2}$,Md. Mohiuddin Sharif ${ }^{3}$, Pratyay Hasan ${ }^{4}$, Md. Maruf Ahmed Molla 5 , \\ Md. Robed Amin 6
}

\begin{abstract}
Background: The present study aimed to describe the association of hematological parameters and common clinico-epidemiological features wit hdisease severity among COVID-19 patients.

Methods: This is a hospital based observational study done in Dhaka Medical College Hospital from OI July 2020 to 15 September 2020. Findings from hematological tests along with patient clinic-pathological features were recorded from a total of 309 COVID-19 patients. All the data were analyzed by SPSS 23.0 software.

Results: Among the studied hematological parameters hemoglobin percentage, total WBC count, lymphocyte percentage, platelet count, CRP, serum ferritin, $d$-dimer, and ESRwere significantly associated with disease severity $(P<0.05)$. Association was found between disease severity and other biochemical markers, such as AST, ALT, LDH, and serum bilirubin.

Conclusion: With limited resources these cheap, yet highly indicative biochemical markers could be used to assess, treat, and prognose COVID-19 patients in Bangladesh.
\end{abstract}

Keywords: COVID-19, SARS-COV-2, CBC, disease severity Bangladesh

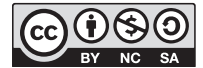

DOI: https://doi.org//0.3329/jom.v22i2.56704

Copyright: (C) 202I Islam MK. This is an open access article published under the Creative Commons Attribution-NonCommercial-NoDerivatives 4.0 International License, which permits use, distribution and reproduction in any medium, provided the original work is properly cited, is not changed in any way and it is not used for commercial purposes.

Received: 23 May 202I;

Accepted: 26 June, 2021

\section{Introduction}

Towards the end of 2019, a sudden uprisinginatypical pneumonia cases was noted in Wuhan, China. ${ }^{1,2}$ Researchers found it to be a novel corona virus and World Health Organization (WHO) confirmed the origin by a statement issued on January 9, 2020. ${ }^{2,3}$ It was named as SARS-CoV-2 virus and the disease was named as COVID -19 by International Committee on Taxonomy of Viruses (ICTV),

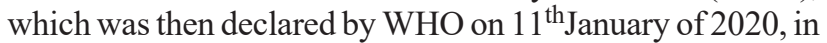
their $22^{\text {nd }}$ situation report of the year. ${ }^{4,5}$

COVID-19 presents as an array of complicated clinical manifestations, from ûu-like symptoms to multiple organ

1. Junior Consultant,Department of Medicine, Dhaka Medical College Hospital, Dhaka

2. Associate Professor, Department of Medicine, Dhaka Medical College Hospital, Dhaka

3. Indoor Medical Officer, Department of Medicine, Dhaka Medical College Hospital, Dhaka

4. Honorary Medical Officer, Department of Medicine, Dhaka Medical College Hospital, Dhaka

5. Medical Officer, Department of Virology, National Institute of Laboratory Medicine and Referral Center

6. Director, NCDC, DGHS, Mohakhali Dhaka and Professor, Department of Medicine, Dhaka Medical College Hospital, Dhaka

Corresponding Author: Mohammad Murad Hossain, Associate, Professor, Department of Medicine, Dhaka Medical College, Dhaka, Mob: 01711112984,Email: mhossaink53@gmail.com failures and death. Most common causes of mortality and morbidities are due to thrombotic complications like pulmonary embolism, DVT and stroke. Several studies have reported evidence on COVID-19 disease being associated with coagulopathy. ${ }^{6-8}$ This pulmonary coagulation and fibrinolysis due to SARS-CoV-2 infection is considered to be regulated by various pro-inflammatory cytokines and similar to pneumonia induced by other pathogens. ${ }^{9-11}$

Neutrophils are one of the most characteristic and important components of the hematopoietic, as well as immune system. It plays a very important role in inflammatory process and modified by mast cells, epithelial cells and macrophages. Neutrophil count from CBC can be uses as marker of any acute infections. ${ }^{12}$

The role of lymphocytes in both inflammation and infection is well established. In viral pneumonia the lymphocyte count isusually increasedbut, surprisingly, in COVID-19 characteristically its count and percentage decreases, resulting in increased neutrophil-lymphocyte, which is often associated with poor patient outcome. ${ }^{13}$ Additionally, thrombocytes play important role in the regulation of various inflammatory processes. While these parameters may be used independently as inflammatory markers, their ratios to one another may also be indicators of early inflammation. ${ }^{14,15}$

The evolving pathophysiology of COVID-19 alsoshowed that it is a pro-thrombotic condition. Furthermore, multivariate 
regression analysis in Chinese COVID-19 cohorts reported that elevated plasma levels of fibrin degradation productd-dimers is associated with poor prognosis in COVID-19 patients. $^{8}$

Parameters such as neutrophil to lymphocyte ratio, platelet count, D-dimer, and prothrombin time might alsobe used as useful markers for classifying and predicting the severity of COVID-19 disease. Several autopsy studies have underlined the contributions of hypercoagulability and associated inflammation in patients who died from COVID-19. ${ }^{16,17}$ The exact pathogenesis of hypercoagulability in COVID-19 isstill under investigations but there are preliminary reports of endothelitis and the involvement of multimericvon Willebrand factor (VWF) with subsequent hypercogulable status. ${ }^{17,18}$

Another studyon COVID-19 patients showed that all the parameter related to thrombosis were increased such as, factor VIII, von Willebrand factor, and fibrinogen. ${ }^{19}$ Other studies also have reported similar findings consistent with a hypercoagulable state, including very high d-dimer level, and increased VWF and factor VIII activity. ${ }^{20}$

Bangladesh with limited resources and less developed healthcare system, often it is challenging to assess various inflammatory cytokines and high-cost genetic markers in management of COVID-19 due to exorbitant cost and limited accessibility. On the contrary, common investigations such as complete blood count (CBC) are relatively cost effective and more convenient. Hence, it is justifiable that $\mathrm{CBC}$ and other common laboratory investigations should hold significance for early diagnosis, management and follow-up of COVID-19 disease. Besides, few studies, up until now have systematically assessed all components of $\mathrm{CBC}$ and other commonly done laboratory investigations and their associations with disease severity in COVID-19 patients. ${ }^{7,21}$ Therefore, the authors hope, this study would address some of those issues and provide important clues regarding association of common biochemical parameters with COVID-19 disease.

\section{Methodology}

Study design and participants selection:

The current study is ahospital based observational study executed prospectively in Dhaka Medical College Hospital (DMCH), Bangladeshbetween 01 July 2020 and 15 September 2020. The study objectivewas to collect and describe thehematological and other investigation reports from a total of 309 CoVID-19 patients and look for anyassociation with disease severity.Participants were recruited using a convenient sampling method and laboratory investigation data were collected from patient treatment sheets.

The patients were divided intofour groups- mild (not included in study), moderate, severe and critical according to National Guidelines on Clinical Management of Coronavirus Disease 2019(COVID-19). ${ }^{22}$

\section{Operational definitions:}

Moderate cases

Fever and respiratory symptoms with radiological findings of pneumonia
Respiratory distress with $<30$ breaths $/$ min

Pulse oxymetry showing saturation $>93 \%$ at ambient air Severe cases

Cases meeting any of the following criteria:

Respiratory distress (g"30 breaths/min);

Finger oxygen saturationd" $93 \%$ at rest;

Arterial partial pressure of oxygen $(\mathrm{PaO} 2) /$ fraction of inspired oxygen (FiO2) f'300mmHg $(\mathrm{mmHg}=0.133 \mathrm{kPa})$

Critical cases

Cases meeting any of the following criteria,

Respiratory failure and requiring mechanical ventilation.

Shock.

With other organ failure that requires ICU care.

\section{Inclusion and exclusion criteria}

Individuals diagnosed as positive COVID-19 by rt-PCR method and aged $>18$ years were included within the study. Mild cases were excluded as at triage during admission patients with mild disease were advised to stay at home and receive symptomatic management. Patientsreceiving prior parenteral and or oral anticoagulant were excluded from the study. The pretested, structured case record form was used to enroll patients at admission in different wards.

\section{Laboratory procedures}

The blood was collected by taking all aseptic precautions. For the complete blood count (CBC), EDTA tubes and Sysmex autolyzer were used. d-dimer was assessedusing tubes treated with sodium citrate,STA-R evolution coagulation analyser and original reagents (Diagnostica Stago, SaintDenis, France). For bilirubin measurement, JM-103 transcutaneous bilirubinometer was used.C-reactive protein in serum was estimated by Nephelometric System by using commercial kit (Dade Behring BN 100, USA). Serum ferritin was measured by using XYEM enzymelinked immunosorbent assay (ELISA) test using ELISA reader. Procalcitonin measurement was performed by enzyme-linked fluorescent assay (B.R.A.H.M.S.;Diagnostica AG, Hennigsdorf/Berlin, Germany) $\mathrm{CBC}$ and coagulation tests (e.g. d-dimer) were done in the Department of Hematology, and the rest of the tests in Department of Clinical Pathology, Dhaka Medical College Hospital.

\section{Statistical analyses}

Continuous variables were expressed as mean $( \pm$ SD)and median (IQR). For comparing means, the nonparametric Kruskal-Wallis test was used. A two-tailed p-value of less than 0.05 was considered statistically significant. The authors performed statistical analysis using SPSS software (version 23.0, IBM, USA).

\section{Ethical approval}

No patient was interviewed during the whole study process and hence informed written consent from participants was 
waived. The study was approved by the ethical review committee of Dhaka Medical College.

\section{Results:}

A total of 309 patients were included in the study, with a mean age of $51.81( \pm 14.44)$ years, and a median age of $52.00(40.00$ $63.00)$ years. Among them, $239(77.6 \%)$ were males and 69 $(22.4 \%)$ were females. Out of these 309 patients, $178(68.7 \%)$ presented with moderate class severity, $69(26.6 \%)$ patients with severe class severity, and only $12(4.6 \%)$ were identified as critical COVID-19 cases. The most common comorbidity was hypertension (63.8\%), closely followed by diabetes mellitus (49.5\%) and then successively by ischemic heart disease, asthma and COPD, CKD, etc.(Table-1)

Significant statistical association was observed between disease severity and hemoglobin percentage, total WBC count, lymphocyte percentage, total platelet count, ESR, CRP, ferritin, ALT, AST, d-dimer, serum bilirubin and LDH $(\mathrm{p}<0.05)$.(Table 2)
Table-I

Baseline characteristics of the patients $(n=309)$

\begin{tabular}{llcc}
\hline \multirow{2}{*}{ Age (Years) } & \multicolumn{2}{c}{$\begin{array}{c}\text { Count }(\mathrm{n}) \\
\text { Mean: } 51.81( \pm 14.44) \\
\text { Median: } 53.00( \pm 40.00-63.00)\end{array}$} \\
\hline Sex & Male & 239 & $77.6 \%$ \\
& Female & 69 & $22.4 \%$ \\
WHO Class & Moderate & 178 & $68.7 \%$ \\
& Severe & 69 & $26.6 \%$ \\
& Critical & 12 & $4.6 \%$ \\
Hypertension & 194 & $63.8 \%$ & \\
Diabetes mellitus & 151 & $49.5 \%$ & \\
Ischemic heart disease & 52 & $17.3 \%$ \\
Asthma & 38 & $12.6 \%$ \\
Chronic obstructive & 22 & $7.3 \%$ \\
pulmonary disease & & & \\
Chronic kidney disease & 33 & $10.9 \%$ \\
Malignancy & 5 & $1.7 \%$ \\
\hline
\end{tabular}

Table-II

Distribution of hematological and common laboratory parameters across the grades of severity according to National Guideline $(n=309)$

\begin{tabular}{|c|c|c|c|c|c|c|c|c|c|}
\hline & \multicolumn{2}{|c|}{ Total } & \multicolumn{2}{|c|}{ Moderate $(n=178)$} & \multicolumn{2}{|c|}{ Severe $(n=69)$} & \multicolumn{2}{|c|}{ Critical $(n=12) \mathrm{P}^{*}$} & \\
\hline & $\begin{array}{l}\text { Mean } \\
( \pm \text { SD })\end{array}$ & $\begin{array}{c}\text { Median } \\
(\mathrm{IQR})\end{array}$ & $\begin{array}{l}\text { Mean } \\
( \pm \text { SD })\end{array}$ & $\begin{array}{c}\text { Median } \\
(\mathrm{IQR})\end{array}$ & $\begin{array}{l}\text { Mean } \\
( \pm \text { SD })\end{array}$ & $\begin{array}{c}\text { Median } \\
(\mathrm{IQR})\end{array}$ & $\begin{array}{l}\text { Mean } \\
( \pm \text { SD })\end{array}$ & $\begin{array}{c}\text { Median } \\
(\mathrm{IQR})\end{array}$ & \\
\hline Hem & 12.26 & 12.3 & 12.38 & 12.4 & 10.62 & 12.3 & 10.62 & 10.8 & \\
\hline$(\mathrm{g} / \mathrm{dI}$ & $( \pm 1.78)$ & $(11.1-13.6)$ & $( \pm 1.86)$ & $(11.3-13.7)$ & $( \pm 0.97)$ & $(10.8-13.4)$ & $( \pm 0.97)$ & $(10-11.4)$ & 0.001 \\
\hline Total WBC & 5105.91 & 5190 & 4911.48 & 4835 & 9187.5 & 4900 & 9187.5 & 9950 & \\
\hline$\left(/ \mathrm{mm}^{3}\right)$ & $( \pm 5050.07)$ & $(9.4-9310)$ & $( \pm 4872.17)$ & $(8.8-8850)$ & $( \pm 3383.2)$ & $(9.4-9530)$ & $( \pm 3383.2)$ & $(6715-12240)$ & 0.017 \\
\hline $\begin{array}{l}\text { Neutrophils } \\
(\%)\end{array}$ & $\begin{array}{c}70.97 \\
( \pm 12.87)\end{array}$ & $\begin{array}{c}72 \\
(62-81\end{array}$ & $\begin{array}{c}70.1 \\
( \pm 12.01\end{array}$ & $\begin{array}{c}70 \\
(62-78)\end{array}$ & $\begin{array}{c}72.17 \\
( \pm 12.36)\end{array}$ & $\begin{array}{c}77 \\
(62-84)\end{array}$ & $\begin{array}{c}72.17 \\
( \pm 12.36)\end{array}$ & $\begin{array}{c}72.5 \\
(62-82)\end{array}$ & 0.115 \\
\hline $\begin{array}{l}\text { Lymphocytes } \\
(\%)\end{array}$ & $\begin{array}{c}19.28 \\
( \pm 10.31)\end{array}$ & $\begin{array}{c}17 \\
(12-24)\end{array}$ & $\begin{array}{c}20.69 \\
( \pm 10.06)\end{array}$ & $\begin{array}{c}20 \\
(13-26)\end{array}$ & $\begin{array}{c}16 \\
( \pm 7.56)\end{array}$ & $\begin{array}{c}12 \\
(10-20)\end{array}$ & $\begin{array}{c}16 \\
( \pm 7.56)\end{array}$ & $\begin{array}{c}13 \\
(10.5-20.5)\end{array}$ & $<0.001$ \\
\hline $\begin{array}{l}\text { Total platelets } \\
\left(/ \mathrm{mm}^{3}\right)\end{array}$ & $\begin{array}{c}922.02 \\
( \pm 10249.68)\end{array}$ & $\begin{array}{c}239 \\
(191-340)\end{array}$ & $\begin{array}{c}272.25 \\
( \pm 104.35)\end{array}$ & $\begin{array}{c}235 \\
(198-326)\end{array}$ & $\begin{array}{c}359.5 \\
( \pm 126.88)\end{array}$ & $\begin{array}{c}239 \\
(170-334)\end{array}$ & $\begin{array}{c}359.5 \\
( \pm 126.88)\end{array}$ & $\begin{array}{c}370 \\
(296-420.5)\end{array}$ & 0.026 \\
\hline $\begin{array}{l}\mathrm{ESR} \text { (mm at } \\
1 \mathrm{st} \text { minute) }\end{array}$ & $\begin{array}{c}33.12 \\
( \pm 22.89)\end{array}$ & $\begin{array}{c}29 \\
(16-40)\end{array}$ & $\begin{array}{c}31.2 \\
( \pm 23.15)\end{array}$ & $\begin{array}{c}26.5 \\
(15-35.5)\end{array}$ & $4( \pm)$. & $\begin{array}{c}34 \\
(23-60)\end{array}$ & $4( \pm)$. & $\begin{array}{c}4 \\
(4-4)\end{array}$ & 0.012 \\
\hline $\begin{array}{l}\text { CRP } \\
(\mathrm{mg} / \mathrm{dL})\end{array}$ & $\begin{array}{c}41.4 \\
( \pm 50.19)\end{array}$ & $\begin{array}{c}24.5 \\
(8-55.05)\end{array}$ & $\begin{array}{c}27.15 \\
( \pm 29.59)\end{array}$ & $\begin{array}{c}21 \\
(6-31)\end{array}$ & $\begin{array}{c}152.07 \\
( \pm 106.93)\end{array}$ & $\begin{array}{c}47 \\
(23-82)\end{array}$ & $\begin{array}{c}152.07 \\
( \pm 106.93)\end{array}$ & $\begin{array}{c}134.5 \\
(95-181.5)\end{array}$ & $<0.001$ \\
\hline $\begin{array}{l}\text { Ferritin } \\
(\mathrm{ng} / \mathrm{ml})\end{array}$ & $\begin{array}{c}659.81 \\
( \pm 507.41)\end{array}$ & $\begin{array}{c}504 \\
(340-897)\end{array}$ & $\begin{array}{c}562.21 \\
( \pm 518.81)\end{array}$ & $\begin{array}{c}397 \\
(250-664)\end{array}$ & $\begin{array}{c}823.58 \\
( \pm 468.6)\end{array}$ & $\begin{array}{c}729.5 \\
(540-1129)\end{array}$ & $\begin{array}{c}823.58 \\
( \pm 468.6)\end{array}$ & $\begin{array}{c}751 \\
(477-1016)\end{array}$ & $<0.001$ \\
\hline $\begin{array}{l}\text { ALT } \\
(\mathrm{IU} / \mathrm{L})\end{array}$ & $\begin{array}{c}50.51 \\
( \pm 37.64)\end{array}$ & $\begin{array}{c}42 \\
(29-56)\end{array}$ & $\begin{array}{c}45.47 \\
( \pm 37.02)\end{array}$ & $\begin{array}{c}38 \\
(26-51)\end{array}$ & $\begin{array}{c}82.64 \\
( \pm 45.84)\end{array}$ & $\begin{array}{c}52 \\
(36-62)\end{array}$ & $\begin{array}{c}82.64 \\
( \pm 45.84)\end{array}$ & $\begin{array}{c}57 \\
(55-113)\end{array}$ & $<0.001$ \\
\hline $\begin{array}{l}\mathrm{AST} \\
\text { (IU/L) }\end{array}$ & $\begin{array}{c}36.56 \\
( \pm 16.12)\end{array}$ & $\begin{array}{c}33 \\
(22-54)\end{array}$ & $\begin{array}{c}33.37 \\
( \pm 14.62)\end{array}$ & $\begin{array}{c}30 \\
(21-40.5)\end{array}$ & $\begin{array}{c}30 \\
( \pm .)\end{array}$ & $\begin{array}{c}54 \\
(39-56)\end{array}$ & $\begin{array}{c}30 \\
( \pm .)\end{array}$ & $\begin{array}{c}30 \\
(30-30)\end{array}$ & 0.007 \\
\hline $\begin{array}{l}\mathrm{D} \text { dimer } \\
(\mu \mathrm{g} / \mathrm{mL})\end{array}$ & $\begin{array}{c}0.6 \\
( \pm 1.08)\end{array}$ & $\begin{array}{c}0.31 \\
(0.1-0.5)\end{array}$ & $\begin{array}{c}0.47 \\
( \pm 0.7)\end{array}$ & $\begin{array}{c}0.2 \\
(0.1-0.5)\end{array}$ & $\begin{array}{c}0.61 \\
( \pm 0.83)\end{array}$ & $\begin{array}{c}0.5 \\
(0.2-0.86)\end{array}$ & $\begin{array}{c}0.61 \\
( \pm 0.83)\end{array}$ & $\begin{array}{c}0.41 \\
(0.15-0.63)\end{array}$ & 0.002 \\
\hline $\begin{array}{l}\text { LDH } \\
(\mathrm{U} / \mathrm{L})\end{array}$ & $\begin{array}{c}424.65 \\
( \pm 221.31)\end{array}$ & $\begin{array}{c}343 \\
(280-525)\end{array}$ & $\begin{array}{c}370.24 \\
( \pm 188.53)\end{array}$ & $\begin{array}{c}307 \\
(266-408)\end{array}$ & $\begin{array}{c}410.42 \\
( \pm 128.04)\end{array}$ & $\begin{array}{c}507 \\
(350-756)\end{array}$ & $\begin{array}{c}410.42 \\
( \pm 128.04)\end{array}$ & $\begin{array}{c}407 \\
(311-518.5)\end{array}$ & $<0.001$ \\
\hline Bilirubin & $\begin{array}{c}0.41 \\
( \pm 0.29)\end{array}$ & $\begin{array}{c}0.45 \\
(0.1-0.6)\end{array}$ & $\begin{array}{c}0.51 \\
( \pm 0.25)\end{array}$ & $\begin{array}{c}0.5 \\
(0.43-0.6)\end{array}$ & $( \pm)$. & $\begin{array}{c}0.1 \\
(0.1-0.42)\end{array}$ & $( \pm)$. &.$(.-)$. & 0.048 \\
\hline Troponin I & $\begin{array}{c}0.04 \\
( \pm 0.19)\end{array}$ & $\begin{array}{c}0.01 \\
(0.01-0.01)\end{array}$ & $\begin{array}{c}0.04 \\
( \pm 0.22)\end{array}$ & $\begin{array}{c}0.01 \\
(0.01-0.01)\end{array}$ & $\begin{array}{l}0.01 \\
( \pm 0)\end{array}$ & $\begin{array}{c}0.01 \\
(0.01-0.01)\end{array}$ & $\begin{array}{l}0.01 \\
( \pm 0)\end{array}$ & $\begin{array}{c}0.01 \\
(0.01-0.01)\end{array}$ & 0.114 \\
\hline Procalcitonin & $\begin{array}{c}0.24 \\
( \pm 1.73)\end{array}$ & $\begin{array}{c}0.05 \\
(0.05-0.05)\end{array}$ & $\begin{array}{c}0.06 \\
( \pm 0.06)\end{array}$ & $\begin{array}{c}0.05 \\
(0.05-0.05)\end{array}$ & $\begin{array}{c}0.05 \\
( \pm 0.01)\end{array}$ & $\begin{array}{c}0.05 \\
(0.05-0.05)\end{array}$ & $\begin{array}{c}0.05 \\
( \pm 0.01)\end{array}$ & $\begin{array}{c}0.05 \\
(0.05-0.05)\end{array}$ & 0.654 \\
\hline
\end{tabular}

*Calculated from comparing the means of the variables across 3 groups of the WHO grades of severity, employing non parametric Kruskal Wallis test. SPSS version 23.0 (IBM, USA) 


\section{Discussion}

Baseline characteristics

Among the study patients, the authors found that the admitted patients are predominantly aged more than 50 years and it seems that predominantly males are the sufferer. This observation was consistently seen in previous clinical studies from China and USA. ${ }^{23-29}$ The national guideline based clinical criteria of severity was observed to be moderate in most of the cases while only 4.6 percent cases were of critical severity. This is also consistent with the prior report from China. ${ }^{30,31}$ The observation also showed that hypertension and DM was the common comorbidity in hospitalized COVID-19 cases and these were also observed in previous studies. ${ }^{32,33}$

\section{Common CBC parameters}

Taneri et al. conducted a meta-analysis including 189 unique studies, with data from 57,563 CoVID-19 patients and found pooled mean hemoglobin and ferritin levels in COVID-19 patients across all ages were $129.7 \mathrm{~g} / \mathrm{L}(95 \% \mathrm{CI}$ : 128.51-130.88) and $777.33 \mathrm{ng} / \mathrm{mL}$ (95\% CI, 701.33-852.77), respectively. ${ }^{34}$ Hemoglobin levels were lower among patients with older age, higher percentage of subjects with diabetes, hypertension and overall comorbidities, and admitted to intensive care. ${ }^{34}$ Cavezzi et al. hypothesized that COVID-19 is more than simply a pulmonary inflammation, and there is hemoglobinopathy, dysregulation of iron metabolism causing altered oxygen transport and ultimately oxygen deprivation. ${ }^{35}$ Majeeed and Shajar suggested that the focus of treatment of COVID-19 would need to shift towards maintaining the oxygen carrying capacity of blood and for this purpose, blood transfusions, super-oxygenation, hyperbaric oxygen therapy could be employed. ${ }^{36}$ Authors in this study would like to suggest similar management among admitted COVID19 patients.

In this study, both mean and median values for lymphocyte count decreased progressively with increasing of severity. Huang and Pranata found in a meta-analysis that patients with poor outcome have a lower lymphocyte count (mean difference " 361.06 iL [" 439.18, " 282.95], p < 0.001; I2 84\%) compared to those with good outcome. ${ }^{37}$ Zhao and Meng also reported similar findings citing a significant reduction of lymphocyte count in the severe COVID-19 group compared to the non-severe group, and those with lymphopenia have a 3-fold higher risk of developing severe COVID-19 patients. ${ }^{38}$ Tavakolpour et al. also reported of similar findings. 39

The authors in this study also found statistical associations $(\mathrm{p}<0.05)$ with total WBC count per cubic millimeter with severity of disease.
Inflammatory markers and acute phase reactants (CRP, ESR, ferritin)

In this study,mean value of CRP was different amongpatient groups and was found to be statistically highly significant $(p<0.001)$. Wang L reported that in the early stage of COVID19, C-reactive protein levels can reflect the extent of lung lesions and disease severity and also can reflect disease changes. ${ }^{40}$ Chen et al. reported that the level of plasma CRP was positively correlated to the severity of COVID-19 pneumonia. Higher plasma CRP level indicated severe COVID19 pneumonia and longer inpatients duration. ${ }^{41}$ Sahu et al. reported that concentrations of CRP remained high in patients who died of CoVID-19 infection and could be a promising biomarker for assessing disease severity. ${ }^{42}$

A pooled analysis of three studies by Lapic et al. comprising total 819 patients revealed that COVID-19 cases were associated with prominent elevations of ESR, as compared to non-severe cases. ${ }^{43-46}$ Elevation in ESR may be caused by the inflammatory process and expression of acute-phase proteins.

In this study, the mean ferritin level was 659.81 ( \pm 507.41$) \mathrm{ng} /$ $\mathrm{ml}$ and means were different among the patient groups and theassociation with disease severity was statistically highly significant $(\mathrm{p}<0.001)$. Moreover, ferritin levels on admission were between 1.5 and 5.3 times higher in patients classified with severe disease in comparison to patients with lesssevere COVID-19 disease. ${ }^{47}$ Vargus-Vargus and Cortés-Rojo hypothesized that by decreasing ferritin level with desforoxamine, researchers can possibly control immune dysregulation and prevent cytokine storm in COVID-19 patients. ${ }^{48}$ Gomez-Pastora et al. reported that average ferritin concentration was $>800 \mathrm{ig} / \mathrm{L}$ for patients. They also provided similar opinion to Vargus-Vargus and Cortés-Rojo. ${ }^{47,48}$ It has been hypothesized by many researchers including, Rosário et al., Gomez-Pastora et al and Vargus-Vargus and Cortés-Rojo that ferritin may have significant role in inflammation, other than its classical role as iron storage, and it seems ferritin is related with severity of the disease. In fact, Rosário et al. described its role in other inflammatory disorders like, macrophage activation syndrome, Still's disease, septic shock and catastrophic antiphospholipid syndrome and proposed a name for these diseases collectively as the "Hyperferrinimic Syndrome". ${ }^{49}$ Here, it should be remembered that ferritin level is also commonly found high in dengue. Soundravally et al. found that the elevated ferritin level could predict the disease severity with sensitivity and specificity of 76.9 and $83.3 \%$, respectively, on the day of admission and the same was found to be 90 and $91.6 \%$ around defervescence. ${ }^{50}$ 


\section{Liver enzymes}

In this study, the mean ALT level was mildly raised and having association with severity or death.But,Zhou et al. reported that risk for in hospital death is associated with ALT $>40$ (OR: 2.87 [1.48 5.57]; $\mathrm{P}=0.0018) .{ }^{51}$ Associations of ALT with severe disease in COVID-19 have been reported by many other researchers. ${ }^{43,51-53}$

In this study the authors foundassociations between AST and disease severity. Xu et al. showed in review of 12 articles that AST was the most frequently elevated liver function test parameter and more frequently elevated in severe diseases. ${ }^{54}$

\section{Other laboratory findings (LDH, bilirubin, d-dimer)}

In our study, the mean value of LDH was raised especially in severe cases. Henry et al. reported that elevated LDH levels were associated with a 6-fold increase in odds of developing severe disease and a 16-fold increase in odds of mortality in patients with COVID-19. ${ }^{55} \mathrm{Wu}$ reported that LDH has good specificity to predict disease progression. ${ }^{56}$ Poggiali et al. reported that elevated $\mathrm{LDH}$ and CRP serum concentrations are associated to respiratory failure in COVID-19 patients. ${ }^{57}$

In this study, the mean value of d-dimer was raised and difference among the grades of severity was statistically significant $(p=0.002)$. Yao et al. reported that $d$-dimer is commonly elevated in patients with COVID-19. d-dimer levels correlate with disease severity and are a reliable prognostic marker for in-hospital mortality in patients admitted with COVID-19. ${ }^{58}$ In a meta-analysis pooling six original studies enrolling 1355 hospitalized patients Sakk et al. reported that d-Dimer levels were found to be higher in non-survivors than in-survivors. 59

\section{Study limitation:}

The blood reports of sequential dayof illness were not observed in this study due to lack of uniformity in all 309 cases. Besides, the Study was limited to a single hospital in Dhaka City.

\section{Conclusion}

Being acquainted withthe common laboratory parameters associated with severity of COVID-19 may help clinicians\& health care providers informulating proper management strategies at early stageof the disease.In poor resource settings like Bangladesh, this knowledge may help indiminution of expenditure in laboratory investigations.

\section{Acknowledgement:}

The authors would like to acknowledge the contributions of all COVID-19 frontline healthcare workers in Bangladesh for their dedication and support during this pandemic.

\section{Funding:}

No funding as received for this study

\section{Conflict of interest:}

Nothing to disclose

\section{References}

1. Huang C, Wang Y, Li X, Ren L, Zhao J, Hu Y, et al. Clinical features of patients infected with 2019 novel coronavirus in Wuhan, China. Lancet. 2020 15;395(10223):497-506.

2. Zhu N, Zhang D, Wang W, Li X, Yang B, Song J, et al. A Novel Coronavirus from Patients with Pneumonia in China, 2019. N Engl J Med. 2020 Feb 20;382(8):727-33.

3. WHO Statement Regarding Cluster of Pneumonia Cases in Wuhan, China [Internet]. [cited 2020 Sep 28]. Available from: https://www.who.int/china/news/detail/09-01-2020-whostatement-regarding-cluster-of-pneumonia-cases-in-wuhanchina

4. International Committee on Taxonomy of Viruses (ICTV) [Internet]. International Committee on Taxonomy of Viruses (ICTV). [cited 2020 Sep 28]. Available from: https:// talk.ictvonline.org/

5. World Health Organization (WHO). February 11, 2020 WHO Novel Coronavirus (2019-nCoV) Situation Report - 22 [Internet]. [cited 2020 Sep 28]. Available from: https:// www.who.int/docs/default-source/coronaviruse/situationreports/20200211-sitrep-22-ncov.pdf?sfvrsn=fb6d49b1_2.

6. Wang D, Hu B, Hu C, Zhu F, Liu X, Zhang J, et al. Clinical Characteristics of 138 Hospitalized Patients with 2019 Novel Coronavirus-Infected Pneumonia in Wuhan, China. JAMA Journal of the American Medical Association. 2020;323(11):1061-9.

7. Tang N, Li D, Wang X, Sun Z. Abnormal coagulation parameters are associated with poor prognosis in patients with novel coronavirus pneumonia. Journal of Thrombosis and Haemostasis. 2020;18(4):844-7.

8. Zhou F, Yu T, Du R, Fan G, Liu Y, Liu Z, et al. Clinical course and risk factors for mortality of adult inpatients with COVID19 in Wuhan, China: a retrospective cohort study. The Lancet. 2020 Mar;395(10229):1054-62.

9. Fung SY, Yuen KS, Ye ZW, Chan CP, Jin DY. A tug-of-war between severe acute respiratory syndrome coronavirus 2 and host antiviral defence: lessons from other pathogenic viruses. Emerging Microbes and Infections. 2020;9(1):55870.

10. Schultz MJ, Haitsma JJ, Zhang H, Slutsky AS. Pulmonary coagulopathy as a new target in therapeutic studies of acute lung injury or pneumonia - A review. Critical Care Medicine. 2006;34(3):871-7.

11. Tang N, Li D, Wang X, Sun Z. Abnormal coagulation parameters are associated with poor prognosis in patients with novel coronavirus pneumonia. J Thromb Haemost. 2020;18(4):844-7.

12. Yazar FM, Bakacak M, Emre A, Urfalýoglu A, Serin S, Cengiz E, et al. Predictive role of neutrophil-to-lymphocyte and platelet-to-lymphocyte ratios for diagnosis of acute 
appendicitis during pregnancy. Kaohsiung J Med Sci. 2015 Nov;31(11):591-6.

13. Yang A-P, Liu J, Tao W, Li H. The diagnostic and predictive role of NLR, d-NLR and PLR in COVID-19 patients. Int Immunopharmacol. $2020 \mathrm{Jul} ; 84: 106504$.

14. Liu J, Li S, Zhang S, Liu Y, Ma L, Zhu J, et al. Systemic immune-inflammation index, neutrophil-to-lymphocyte ratio, platelet-to-lymphocyte ratio can predict clinical outcomes in patients with metastatic non-small-cell lung cancer treated with nivolumab. J Clin Lab Anal. 2019 Oct;33(8):e22964.

15. Ýlhan M, Ýlhan G, Gök AFK, Bademler S, Verit Atmaca F, Ertekin C. Evaluation of neutrophil-lymphocyte ratio, platelet-lymphocyte ratio and red blood cell distribution width-platelet ratio as early predictor of acute pancreatitis in pregnancy. J Matern Fetal Neonatal Med. 2016; 29(9):1476-80.

16. Menter T, Haslbauer JD, Nienhold R, Savic S, Hopfer H, Deigendesch N, et al. Postmortem examination of COVID19 patients reveals diffuse alveolar damage with severe capillary congestion and variegated findings in lungs and other organs suggesting vascular dysfunction. Histopathology. 2020;77(2):198-209.

17. Wichmann D, Sperhake JP, Lütgehetmann M, Steurer S, Edler C, Heinemann A, et al. Autopsy Findings and Venous Thromboembolism in Patients With COVID-19: A Prospective Cohort Study. Annals of internal medicine. 2020;173(4):268-77.

18. Léonard-Lorant I, Delabranche X, Séverac F, Helms J, Pauzet $\mathrm{C}$, Collange $\mathrm{O}$, et al. Acute Pulmonary Embolism in Patients with COVID-19 at CT Angiography and Relationship to dDimer Levels. Radiology. 2020;296(3):E189-91.

19. Panigada M, Bottino N, Tagliabue P, Grasselli G, Novembrino C, Chantarangkul V, et al. Hypercoagulability of COVID-19 patients in intensive care unit: A report of thromboelastography findings and other parameters of hemostasis. J Thromb Haemost. 2020;18(7):1738-42.

20. Helms J, Tacquard C, Severac F, Leonard-Lorant I, Ohana $\mathrm{M}$, Delabranche X, et al. High risk of thrombosis in patients with severe SARS-CoV-2 infection: a multicenter prospective cohort study. Intensive Care Med. 2020 May 4;1-10.

21. Fogarty H, Townsend L, Ni Cheallaigh C, Bergin C, MartinLoeches I, Browne P, et al. COVID19 coagulopathy in Caucasian patients. British Journal of Haematology. 2020;189(6):1044-9.

22. Shahnila Ferdousi, ABM Abdullah, MA Faiz, Khan Abul Kalam Azad, Ahmedul Kabir, Md Robed Amin, et al., editors. National Guidelines on Clinical Management of Coronavirus Disease 2019 (COVID-19). 7th ed. Disease Control Division, Directorate General of Health Services (DGHS) under the Ministry of Health \& Family Welfare (MOHFW),
Government of the People's Republic of Bangladesh; 2020. $18 \mathrm{p}$.

23. Bwire GM. Coronavirus: Why Men are More Vulnerable to Covid-19 Than Women? SN Compr Clin Med. 2020 Jun $4 ; 1-3$.

24. Jordan RE, Adab P, Cheng KK. Covid-19: risk factors for severe disease and death. BMJ. 2020 26;368:m1198.

25. Shim E, Tariq A, Choi W, Lee Y, Chowell G. Transmission potential and severity of COVID-19 in South Korea. Int J Infect Dis. 2020 Apr;93:339-44.

26. Karnam G, Rygiel TP, Raaben M, Grinwis GCM, Coenjaerts FE, Ressing ME, et al. CD200 receptor controls sex-specific TLR7 responses to viral infection. PLoS Pathog. 2012;8(5):e1002710.

27. Ghazeeri G, Abdullah L, Abbas O. Immunological differences in women compared with men: overview and contributing factors. Am J Reprod Immunol. 2011 Sep;66(3):163-9.

28. Zhao Y, Zhao Z, Wang Y, Zhou Y, Ma Y, Zuo W. Single-Cell RNA Expression Profiling of ACE2, the Receptor of SARSCoV-2. Am J Respir Crit Care Med. 2020 01;202(5):756-9.

29. Onder G, Rezza G, Brusaferro S. Case-Fatality Rate and Characteristics of Patients Dying in Relation to COVID-19 in Italy. JAMA. 2020 May 12;323(18):1775-6.

30. Gao Y. COVID-19: Risk factors for critical illness. EClinicalMedicine [Internet]. 2020 Aug 1 [cited 2020 Sep 28];25. Available from: https://www.thelancet.com/journals/ eclinm/article/PIIS2589-5370(20)30251-0/abstract

31. Guan W-J, Ni Z-Y, Hu Y, Liang W-H, Ou C-Q, He J-X, et al. Clinical Characteristics of Coronavirus Disease 2019 in China. The New England Journal of Medicine. 2020;382(18):17081720 .

32. Sanyaolu A, Okorie C, Marinkovic A, Patidar R, Younis K, Desai $\mathrm{P}$, et al. Comorbidity and its Impact on Patients with COVID-19. SN Compr Clin Med. 2020 Jun 25;1-8.

33. Richardson S, Hirsch JS, Narasimhan M, Crawford JM, McGinn T, Davidson KW, et al. Presenting Characteristics, Comorbidities, and Outcomes Among 5700 Patients Hospitalized With COVID-19 in the New York City Area. JAMA. 2020 May 26;323(20):2052-9.

34. Taneri PE, Gómez-Ochoa SA, Llanaj E, Raguindin PF, Rojas LZ, Roa-Díaz ZM, et al. Anemia and iron metabolism in COVID-19: a systematic review and meta-analysis. Eur J Epidemiol. 2020 Aug 1;35(8):763-73.

35. Cavezzi A, Troiani E, Corrao S. COVID-19: hemoglobin, iron, and hypoxia beyond inflammation. A narrative review. Clin Pract [Internet]. 2020 May 28 [cited 2020 Sep 15];10(2). Available from: https:/www.ncbi.nlm.nih.gov/pmc/articles/ PMC7267810/ 
36. Majeed A, Shajar MA. Is hemoglobin the missing link in the pathogenesis of COVID-19? Anaesth Pain Intensive Care. 2020;9-12.

37. Huang I, Pranata R. Lymphopenia in severe coronavirus disease-2019 (COVID-19): systematic review and metaanalysis. Journal of Intensive Care. 2020 May 24;8(1):36.

38. Zhao Q, Meng M, Kumar R, Wu Y, Huang J, Deng Y, et al. Lymphopenia is associated with severe coronavirus disease 2019 (COVID-19) infections: A systemic review and metaanalysis. International Journal of Infectious Diseases. 2020 Jul 1;96:131-5.

39. Tavakolpour S, Rakhshandehroo T, Wei EX, Rashidian M. Lymphopenia during the COVID-19 infection: What it shows and what can be learned. Immunol Lett. 2020 Sep;225:31-2.

40. Wang L. C-reactive protein levels in the early stage of COVID19. Médecine et Maladies Infectieuses. 2020 Jun $1 ; 50(4): 332-4$.

41. Chen W, Zheng KI, Liu S, Yan Z, Xu C, Qiao Z. Plasma CRP level is positively associated with the severity of COVID19. Annals of Clinical Microbiology and Antimicrobials. 2020 May 15;19(1):18.

42. Sahu BR, Kampa RK, Padhi A, Panda AK. C-reactive protein: A promising biomarker for poor prognosis in COVID-19 infection. Clin Chim Acta. 2020 Oct;509:91-4.

43. Cai Q, Huang D, Ou P, Yu H, Zhu Z, Xia Z, et al. COVID 19 in a designated infectious diseases hospital outside Hubei Province, China. Allergy. 2020 Jul;75(7):1742-52.

44. Qin C, Zhou L, Hu Z, Zhang S, Yang S, Tao Y, et al. Dysregulation of Immune Response in Patients With Coronavirus 2019 (COVID-19) in Wuhan, China. Clin Infect Dis. 2020 28;71(15):762-8.

45. Wang Z, Yang B, Li Q, Wen L, Zhang R. Clinical Features of 69 Cases With Coronavirus Disease 2019 in Wuhan, China. Clin Infect Dis. 2020 28;71(15):769-77.

46. Lapiæ I, Rogiæ D, Plebani M. Erythrocyte sedimentation rate is associated with severe coronavirus disease 2019 (COVID-19): a pooled analysis. Clinical Chemistry and Laboratory Medicine (CCLM). 2020 Jun 25;58(7):1146-8.

47. Gómez-Pastora J, Weigand M, Kim J, Wu X, Strayer J, Palmer AF, et al. Hyperferritinemia in critically ill COVID19 patients - Is ferritin the product of inflammation or a pathogenic mediator? Clin Chim Acta. 2020 Oct;509:24951.

48. Vargas-Vargas M, Cortés-Rojo C. Ferritin levels and COVID19. Rev Panam Salud Publica [Internet]. 2020 Jun 1 [cited
2020 Sep 15];44. Available from: https://www. ncbi.nlm.nih.gov/pmc/articles/PMC7286435/

49. Rosário C, Zandman-Goddard G, Meyron-Holtz EG, D’Cruz DP, Shoenfeld Y. The hyperferritinemic syndrome: macrophage activation syndrome, Still's disease, septic shock and catastrophic antiphospholipid syndrome. BMC Med. 2013 Aug 22;11:185.

50. Soundravally R, Agieshkumar B, Daisy M, Sherin J, Cleetus CC. Ferritin levels predict severe dengue. Infection. 2015 Feb;43(1):13-9.

51. Zhou F, Yu T, Du R, Fan G, Liu Y, Liu Z, et al. Clinical course and risk factors for mortality of adult inpatients with COVID19 in Wuhan, China: a retrospective cohort study. Lancet. 2020;395(10229):1054-62.

52. Bloom PP, Meyerowitz EA, Reinus Z, Daidone M, Gustafson J, Kim AY, et al. Liver Biochemistries in Hospitalized Patients With COVID 19. Hepatology [Internet]. 2020 May 16 [cited 2020 Sep 15]; Available from: https://onlinelibrary.wiley.com/doi/abs/10.1002/hep.31326

53. Chen N, Zhou M, Dong X, Qu J, Gong F, Han Y, et al. Epidemiological and clinical characteristics of 99 cases of 2019 novel coronavirus pneumonia in Wuhan, China: a descriptive study. The Lancet. 2020 Feb 15;395(10223):50713.

54. Xu X, Liu L, Sharma M, Zhao Y. Smoking-Related Knowledge, Attitudes, Behaviors, Smoking Cessation Idea and Education Level among Young Adult Male Smokers in Chongqing, China. International Journal of Environmental Research and Public Health. 2015 Feb 16;12(2):2135-49.

55. Henry BM, Aggarwal G, Wong J, Benoit S, Vikse J, Plebani $\mathrm{M}$, et al. Lactate dehydrogenase levels predict coronavirus disease 2019 (COVID-19) severity and mortality: A pooled analysis. Am J Emerg Med. 2020 Sep;38(9):1722-6.

56. Wu M, Yao L, Wang Y, Zhu X, Wang X, Tang P, et al. Clinical evaluation of potential usefulness of serum lactate dehydrogenase (LDH) in 2019 novel coronavirus (COVID19) pneumonia. Respiratory Research. 2020 Jul 6;21(1):171.

57. Poggiali E, Zaino D, Immovilli P, Rovero L, Losi G, Dacrema A, et al. Lactate dehydrogenase and C-reactive protein as predictors of respiratory failure in CoVID-19 patients. Clinica Chimica Acta. 2020 Oct 1;509:135-8.

58. Yao Y, Cao J, Wang Q, Shi Q, Liu K, Luo Z, et al. D-dimer as a biomarker for disease severity and mortality in COVID-19 patients: a case control study. Journal of Intensive Care. 2020 Jul 10;8(1):49.

59. Sakka M, Connors JM, Hékimian G, Martin-Toutain I, Crichi B, Colmegna I, et al. Association between D-Dimer levels and mortality in patients with coronavirus disease 2019 (COVID-19): a systematic review and pooled analysis. JMVJournal de Médecine Vasculaire. 2020 Sep 1;45(5):268-74. 